This is the accepted version of an article that has been published by Elsevier in Structural Change and Economic Dynamics on 18 Aug 2018. Published version available from:

https://doi.org/10.1016/i.strueco.2018.07.005

Accepted version made available under CC-BY-NC-ND 4.0 International License from SOAS Research

Online: http://eprints.soas.ac.uk/26304/

\title{
Exploring Macroeconomic Frameworks Conducive to Structural Transformation of Sub-Saharan African Economies
}

\author{
Machiko Nissanke*
}

First draft: 31 July $2016^{* *}$

Final Revision: 28 January 2018

\begin{abstract}
The conventional macroeconomic policy framework, with its focus on maintaining macro stability is inadequate for the purpose of accelerating the structural transformation of African economies. This 'policy position' paper explores an alternative framework, wherein macroeconomic policies are applied coherently to one another and in coordination with other policies, and a resolution of the short-run trade-off between the macroeconomic policy objectives of stabilisation and development is sought in terms of a long-term development approach for enhancing both aggregate demand and supply capacity as an anchor for navigating a path towards structural transformation. After presenting a working definition of structural transformation, the paper presents the core elements of such a framework and discusses the corresponding policy agenda under five headings. Using this agenda as a benchmark, it discusses how to approach the debates on fiscal, monetary and financial policies, avoiding the limitations of standard macroeconomic literature, in order to make those policies conducive to Africa's structural transformation.
\end{abstract}

Key Words: Structural Transformation, Macroeconomic Frameworks, African Development, Fiscal Sustainability and Legitimacy, Monetary and Financial Policy for Development

JEL Code: O21, O23, O25,O43, O55

* Emeritus Professor of Economics, School of Oriental and African Studies, mn2@soas.ac.uk. The paper is initially built on one part of my background paper written for the UN Economic Commission for Africa (UNECA), " Macroeconomic Framework for Structural Transformation of African Economies". However, the arguments and analyses presented in this paper reflect my refined, updated thoughts on the subject since then, hence they are substantially different in several critical aspects from those appeared in my earlier paper (Nissanke, 2014). 
This is the accepted version of an article that has been published by Elsevier in Structural Change and Economic Dynamics on 18 Aug 2018. Published version available from:

https://doi.org/10.1016/i.strueco.2018.07.005

Accepted version made available under CC-BY-NC-ND 4.0 International License from SOAS Research Online: http://eprints.soas.ac.uk/26304/

\section{Introduction}

While structural change is conventionally discussed in terms of sectoral compositional changes in output, or employment, a deeper understanding of transformational processes is required for strategic policy making, which goes well beyond a mere linear progression from a primary-sector dominant structure towards a higher order one. A number of recent studies shed a light on the process of structural transformation. For example, McMillan and Rodrik (2011) argue that structural transformation should be understood as the growth-enhancing structural change resulting from reallocation of resources from low-productivity activities to high-productivity ones across, and within, sectors. Their empirical analysis covering the period of 1990-2005 shows that whilst Asian countries have experienced productivity-enhancing structural changes, productivity-reducing structural changes have been a norm in Africa and Latin America. ${ }^{1}$ Extending an analysis to a longer period between 1960 and 2000, de Vries et al. (2013) further reveal that Africa's relative productivity in relation to the global technological frontier has steadily declined across sectors since the 1980s, and Africa's structural change since the 1990s has been characterised by 'static gains' but accompanied by 'dynamic losses' as labour migrated from both agriculture and manufacturing to fragile informal activities in services with lower marginal productivity.

Emerging consensus indicate that: 1) structural transformation should be associated with overall labour productivity growth and a move into sectors with dynamic growth potentials; 2) productivity-enhancing structural change cannot be expected on the basis of fragile activities regardless of the sectors. Clearly, economies with comparative advantage in natural resources and primary commodity exports are at a disadvantage compared to those with one in human resources and manufacturing goods exports. Countries in Africa and Latin America have failed to get the process of productivityenhancing structural change underway while increasingly integrating into the world economy as globalisation has gathered pace since the early 1990 s.

The pattern of productivity-reducing change in Africa since the mid-1970s is a direct consequence of the extreme paucity of productive investments in both public and private sectors, manifesting itself in a halt to the process of socio-economic development. In the normal development process, fragile informal activities are expected to build up productive assets and capacities so as to graduate into more robust, formal units. Instead, fragile informal activities remain the mainstay of African economies today, as the reverse process of informalisation has taken place. Without rigorous productivity-enhancing investment and skill-technology-knowledge acquisition into new dynamically evolving sectors, Africa's 'revealed' comparative advantage remained static in pre-existing relative resource endowments and it has dominated its integration pattern into the global economy.

\footnotetext{
${ }^{1}$ Their more recent work (McMillan et. al, 2014) suggests some early sign of productivity-enhancing changes in Africa since 2005.
} 
This is the accepted version of an article that has been published by Elsevier in Structural Change and Economic Dynamics on 18 Aug 2018. Published version available from:

https://doi.org/10.1016/i.strueco.2018.07.005

Accepted version made available under CC-BY-NC-ND 4.0 International License from SOAS Research Online: http://eprints.soas.ac.uk/26304/

Structural transformation envisaged in Africa should address these weak conditions associated with 'enclave' and 'fragmented' economic structures as well as with the fragility and vulnerability characterizing informal activities, requiring a strategic approach. Yet, whilst Africa's imperative for structural transformation is now widely acknowledged $^{2}$, there is little agreement on what constitutes an appropriate set of economic policies that are conducive to structural transformation. The conventional macroeconomic policy discourse, with its exclusive focus on maintaining macro stability under the banner of ensuring "sound macro fundamentals" is grossly inadequate in accelerating the pace of structural transformation, or even triggering the transformation process in its earnest.

It is critical to seek a fresh approach to macroeconomic management so as to to fit the purpose of structural transformation of African economies. ${ }^{3}$ Against this background, the prime objective of this paper is to explore an alternative framework wherein macroeconomic policy tools are applied coherent to one another and in coordination with other policies, and a resolution of the short-run trade-off between the two macroeconomic policy objectives- stabilisation and development- is sought with a clear long-term development vision as an anchor for navigating a path towards structural transformation. ${ }^{4}$ The paper is structured as follows: In Section 2 after providing our working definition of structural transformation, we first present an overarching macroeconomic framework and its core constructs for facilitating developmental processes towards structural transformation. This is followed by discussion on five cross-cutting agenda to be addressed by macroeconomic policies located in the framework. Using these five agenda as a benchmark, Section 3 discusses how to reconstruct the debates on fiscal and monetary policies from the confined discourses prevailing in mainstream macroeconomics literature. Section 4 presents concluding remarks.

\section{Macroeconomic Framework and Cross Cutting Policy Agenda for Facilitating the Process of Structural Transformation}

\section{1. A Quest for an overarching Macroeconomic Framework}

Macroeconomic policies derived from the Keynes' General Theory were very much focused on the mission of maintaining aggregate demand through economic cycles. Macroeconomic models subsequently developed were built around the promise that there exists an inherent tension and trade-off between the two objectives - stabilisation and growth - in the short run, while the two objectives can be complementary in the long run. Macroeconomic management was understood as treading carefully this shortrun trade off. However, as discussed below, there has been an increasing tendency to

2 . See, for example, African Development Bank (2017).

${ }^{3}$. Africa and sub-Saharan Africa are used interchangeably throughout, and this paper does not cover countries in North Africa.

${ }^{4}$. Given this objective, this paper is written as an exploratory policy position piece with reference to relevant theory debates, not reporting results of empirical work or theoretical model building exercises. 
This is the accepted version of an article that has been published by Elsevier in Structural Change and Economic Dynamics on 18 Aug 2018. Published version available from:

https://doi.org/10.1016/i.strueco.2018.07.005

Accepted version made available under CC-BY-NC-ND 4.0 International License from SOAS Research Online: http://eprints.soas.ac.uk/26304/

interpret the 'stabilisation' objective simply as achieving price stability in academic and policy discourses since the late 1970s, and macroeconomic policies are predominantly evaluated in terms of ensuring price stability.

Whilst the singling out of price stability as the foremost objective is often rationalised in the discourses of developed economies under the assumption of a near-full employment economy ${ }^{5}$, this bias is unjustifiable for low-income countries with large reserves of unemployed resources to be utilised as productive assets. Such an exclusive focus on maintaining price stability under the banner of ensuring "sound macro fundamentals" is grossly inadequate for facilitating structural transformation of African economies. Clearly, their macroeconomic policy performance should be also evaluated in relation to development goals, and macroeconomic management should set both stabilisation and development as the main objectives.

Now, structural transformation of African economies as envisioned in this paper goes far beyond simple sectoral compositional changes in output or employment. Instead, as illustrated in Figure 1, we argue for it to be understood as development processes involving changes in multiple dimensions of a socio-economic system, including its production matrix, social structure, institutional setting and its relationship with the natural environment. It is only through these multi-dimensional processes that countries could transit from 'enclave' and 'fragmented' structures characterised by the fragility and vulnerability associated with informal activities, towards a well-articulated economy, wherein economic activities are linked closely so that dynamic externalities and demand spillovers are generated to reinforce both static gains from resource reallocation across sectors and dynamic gains from technological advancement economy-wide.

\section{- Insert about here Figure 1-}

Furthermore, only by dynamically shifting from their static 'revealed' comparative advantage inherited from the colonial era through active 'learning-by-doing', could African countries strategically take advantage of emerging opportunities arising from integrating into the global economy and address challenges from new technologydriven trade from a stronger position. A well-articulated economy with a diversified structure encompassing varieties of activities linked together could raise local demand in a self-sustaining manner on the basis of Africa's demographic dividends and regional integration, instead of relying heavily on external demand outside Africa. The more reliance on enlarged home and regional markets with expanding aggregate demand presents a bigger potential of generating secure jobs and gainful employment, creative activities and learning opportunities on a continuous basis. ${ }^{6}$ Inclusive development should become then an integral part of these dynamic processes of structural

\footnotetext{
${ }^{5}$ The Great Recession that followed the GFC of 2008 in advanced economies has led to a reappraisal of macroeconomic theory and policy, including a search for growth-oriented stabilisation policy (e.g. Stiglitz , 2014, Blanchard and Summers, 2017). See Sections 2.2 below for the recent debate on macroeconomic management.

${ }^{6}$ See Stiglitz and Greenwald (2014) for understanding development as a process of creating a 'learning society'.
} 
This is the accepted version of an article that has been published by Elsevier in Structural Change and Economic Dynamics on 18 Aug 2018. Published version available from:

https://doi.org/10.1016/i.strueco.2018.07.005

Accepted version made available under CC-BY-NC-ND 4.0 International License from SOAS Research Online: http://eprints.soas.ac.uk/26304/

transformation. Structural transformation is an evolving process of not only transformation of economic structures but social transformation, proceeding with sharing opportunities ex-ante among all the population, inclusive of, poorer segments regardless of gender, ethnicity and religion or any other divisive criteria. ${ }^{7}$

Clearly, the prevailing conditions in Africa today do pose severe challenge in initiating and sustaining the process of transformation of economic and social structures as outlined above. The reality on the ground is arduous on many fronts. There are still massive deficits in three key areas - human resources, infrastructure, and institutional environments. Addressing them is exigent, since improving each of these areas constitutes an indispensable building block for proceeding to structural transformation and achieving the ultimate goals, as shown in Figure 1. Initiating and accelerating such a transformation process needs a far-sighted strategic stance. It demands purposeful, concerted societal efforts to build productive capacity and assets economy-wide by directing public and private investment into new dynamic high-value added activities with high social returns in many decades ahead. Thus, to kick-start the process, incessant, large-scale investments in all aspects of human resources (education, health, skills and knowledge) as well as economic and social infrastructures are indispensable.

Further, there are close interrelationships between institutional configurations and the quality of policy-making, which jointly determine development outcome through. multi-layer feedback loops in the institutions-policies-development nexus. Our institutions-policies-development triangular nexus implies that a country's institutional configuration as evolved affects its government's ability to formulate and implement development strategies, including macroeconomic policy-making. At the same time, the way these plans and policies are executed would influence institutional configuration and its evolution. Then, the combined effects of institutions and policies determine developmental outcome, which affect the subsequent evolution of institutions. Thus, as one of the main building blocks towards structural transformation, it is necessary to nurture an institutional configuration into developmental one, i.e. a developmental nation-state that is accountable to domestic stakeholders.

With these tasks in mind, we call for a coherent framework, where individual macroeconomic policies - fiscal and monetary policies as well as financial and regulatory policies in the domain of a country's Ministry of Finance and Central Bank - are placed and contextualised. The proposed framework is outlined schematically in Figure 2, in which the macroeconomic framework for structural transformation is embedded in an overarching development strategic plan, which maps a path towards long-term goals set in a country- and region-specific context. Fig.2 also illustrates macroeconomic policies should be executed in coordination with other policies. Whilst the importance of macroeconomic policies for providing overall policy environments is not in doubt, structural transformation as defined cannot be facilitated by macroeconomic policies alone or any individual policy in isolation. It requires the deployment of wide-ranging policies, including trade, technology policies, financial

7. See Nissanke $(2014,2017 a)$ for more detailed discussions on how structural transformation and inclusive development should be understood in the African context, as illustrated in Fig.1 
This is the accepted version of an article that has been published by Elsevier in Structural Change and Economic Dynamics on 18 Aug 2018. Published version available from:

https://doi.org/10.1016/i.strueco.2018.07.005

Accepted version made available under CC-BY-NC-ND 4.0 International License from SOAS Research Online: http://eprints.soas.ac.uk/26304/

sector policies, oversight regulatory and competition policies, social policy, education and health policies as well as sector-specific policies such as industrial or agricultural policies. Macroeconomic policies are tasked with providing pro-investment macro conditions, under which other policies can be executed in a manner that is consistent inter-temporarily and spatially with a view to facilitating structural transformation.

\section{- Insert about here Figure 2-}

Implementing these policies requires a system of endogenously evolved institutions as a country's institutional configuration to navigate the process of structural transformation in a coordinated manner. ${ }^{8}$ In this regard, macroeconomic policy should be designed to be instrumental in laying an institutional foundation for structural transformation by fostering productive private-public interface that would give rise to an emergence of a developmental nation-state. Hence, the two-way interrelationships between policies and institutions are represented in arrows in the upper part of Fig.2. The proposed framework emphases the need for a holistic approach with a system of operational flexibility and coordination to take on the challenge of structural transformation, where a strategic plan is at its helm. ${ }^{9}$ The plan is to provide an anchor and a road map in taking strategic decisions on a rolling basis while navigating macroeconomic policies through the short-run trade-off between the twin objectives of stabilisation and development.

Attending stabilisation needs without undermining development efforts has been a challenge to macroeconomic management in developing countries. Because of structural characteristics of their economies, Sub-Sahara African countries can be singled out as the region that have been susceptible to most hardships by the failure in addressing this 'trade-off' challenge throughout their post-independence years irrespective of the development paradigms adopted. Critically, the stabilisation policies applied were often flawed at its core for sustaining impetus for development. ${ }^{10}$ In the early post-independent years, their development processes were severely constrained despite planning in place largely due to the huge gap between the high vision and aspiration for socio-economic advancement embedded in their development plans, on the one hand, and the state capacity and institutional configurations for implementation on the grounds, on the other. Often than not, the way the state-led development model was adopted and executed, most domestic stakeholders -private firms and rural farmers alike- were largely left disenfranchised from economic development processes and collective efforts in nation-state-building.

Unfortunately, before they had hardly time to build institutional resilience as a nationstate, their development crusade was disrupted by difficulties in adjusting to

\footnotetext{
${ }^{8}$ See Nissanke (2017a) for the concept of endogenously evolved institutions as a country's institutional configuration.

${ }^{9}$ Such a plan is naturally not made up of a set of directives and targets in a particular time horizon, as in a typical centrally planned, command economy.

${ }^{10}$ See Nissanke (2014) for detailed discussions of the evolution of macroeconomic policy frameworks in Africa in the post independent period from this specific angle.
} 
This is the accepted version of an article that has been published by Elsevier in Structural Change and Economic Dynamics on 18 Aug 2018. Published version available from:

https://doi.org/10.1016/i.strueco.2018.07.005

Accepted version made available under CC-BY-NC-ND 4.0 International License from SOAS Research Online: http://eprints.soas.ac.uk/26304/

macroeconomic imbalances in the face of large external shocks in the 1970s. Many countries, which remained overly dependent on primary commodity export revenues for internal and external balances had to pay heavy prices for their external borrowing to ride-through the macroeconomic imbalances and subsequent pro-cyclical spending during the short-lived commodity boom of the 1970s. The boom was followed by the precipitous commodity price collapse at the close of the 1970s, which had led to the protracted sovereign debt crisis, a resolution of which was finally reached by the adoption of the MDRI only in $2005 .^{11}$

In the 1980s and 1990s, macroeconomic stabilisation-cum-adjustment objectives dominated over other developmental objectives. The solutions recommended by the IFIs to debt crises were an adoption of policies of liberalisation and deregulation, and keeping the size of governments to a minimum in exchange for aid money and debt restructuring under the SAPs. In the deregulated environments emerged, there was no place for sectoral policies aiming at fostering selected economic activities or coordinating investments on the part of governments. The remaining role of governments in economic management judged as legitimate was strictly confined to maintaining macroeconomic balances through short-run stabilization policies as designed by the IMF.

What is most disturbing is that incorrect stabilisation policies were applied, which did aggravate further the debt crisis in commodity-dependent low-income countries. These policies were pro-cyclical to exogenous shocks stemming from commodity price swings, rather than counter-cyclical as should be. As the application of the stabilisation policies that ignored the on-going commodity crisis further depressed the economies. The dwindling capacity to undertake public investments on the part of governments burdened with high debt resulted in their inability to promote and crowd-in private investment. Thus, the stocks of productive assets were fast depleted for individuals as well as for the economies as large.

In short, Africa's past experiences with both the state-led development planning of the earlier years and the development guided by market forces only under the SAPs, each of which is derived from the contrasting paradigm respectively, did give rise to common conditions that are particularly detrimental to structural transformation. First there was little sustained productive public investment with a view to enticing private investment.

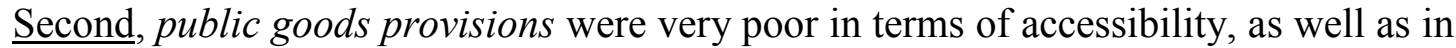
the quality in provision of: i) hard economic infrastructures, i.e. access to reliable public services in power, transport, communication, water, sanitation and others; ii) social expenditures in health and education provision; and iii) soft infrastructures by ensuring public safety and security, reducing transaction and information costs through establishing a stable regulatory structure to exchanges and interactions economy-wide.

11 The outbreak of Africa's debt crisis in the early 1980s was closely connected to that of the severe commodity crisis at the time. See Maizels (1992) and Nissanke (2010a) for a more detailed, exposition. For further discussion of the debt dynamics of the HIPCs, see Nissanke (2010b). 
This is the accepted version of an article that has been published by Elsevier in Structural Change and Economic Dynamics on 18 Aug 2018. Published version available from:

https://doi.org/10.1016/i.strueco.2018.07.005

Accepted version made available under CC-BY-NC-ND 4.0 International License from SOAS Research Online: http://eprints.soas.ac.uk/26304/

These two conditions are closely interrelated. The macroeconomic frameworks under the previous regimes failed to create efficient and capable governments and public institutions to undertake pro-poor public investments on a sustained basis. Weak public investment was the outcome of the fragile fiscal positions resulting from unstable, meagre financial resource bases combined with inadequate institutional capability (technical and organizational) at governments and public agencies. The remedies imposed by the IFIs aggravated the situation as they weakened the state capacity by starving governments off resources for public investment and services. Given little public investments undertaken and no guarantee of covering recurrent costs for operation and maintenance, most public services were unavailable or grossly inadequate in reliability and quality for domestic stakeholders. Such feeble fiscal positions led not only to the fast depletion of physical and human productive assets but also to an institutional low-equilibrium for development. Consequently, Africa's critical bottlenecks in all three key areas - human resources, infrastructure provision, and institutional configurations - are enormous, and reducing them requires consistent and concerted efforts at all levels.

A fresh approach to resolve the trade-off between the stabilisation and development objectives is needed. To date, stabilisation policies are implemented for closing macroeconomic imbalances fast in the name of restoring macro stability. In practice this is accomplished by depleting a country's productive assets by reducing both aggregate demand and supply capacity with a severe setback to its developmental objective. Addressing the trade-off is particularly complicated for countries heavily dependent on primary commodity exports for their external and internal balances, since exogenous shocks from highly volatile cyclical commodity prices, rather than domestic demand conditions, are the prime cause for large swings in their macroeconomic balances. This crucial feature needs to be confronted upfront in formulating macroeconomic policies. Stabilisation policy should be designed and executed by making a correct diagnose of how macro imbalances emerge in the first place. ${ }^{12}$ If imbalances are triggered by external shocks, stabilisation should be applied countercyclically to external shocks. For commodity dependent economies, stabilisation policies should be applied counter-cyclical to commodity price movements: an expansionary stance to stimulate aggregate demand in commodity price slumps, while taming overheating conditions in commodity booms. Yet, when a country is hit by negative external shocks, requiring stand-by loans from the IMF, it is compelled to deploy stabilisation policies to suppress demand for addressing perceived excess in aggregate domestic demand and thereby to reduce deficits in both accounts within a tight timeline specified in loan agreements.

Drawing lessons from their bitter past experiences, many natural resource rich African countries attempted to apply stabilisation policies counter-cyclically over the recent

\footnotetext{
${ }^{12}$ Ocampo and Ross (2006) also note that economic cycles of emerging and developing countries are driven by external shocks such as a dramatic shift in their terms of trade or cross-border private capital flows rather than those of domestic origin. With this mind, they call for policy space in macroeconomic policy.
} 
This is the accepted version of an article that has been published by Elsevier in Structural Change and Economic Dynamics on 18 Aug 2018. Published version available from:

https://doi.org/10.1016/i.strueco.2018.07.005

Accepted version made available under CC-BY-NC-ND 4.0 International License from SOAS Research Online: http://eprints.soas.ac.uk/26304/

commodity super cycle of 2002-2014. ${ }^{13}$ Their accumulated international reserves or savings lodged in Sovereign Wealth Funds or Stabilisation Funds established during the boom helped several countries to adopt stimulus packages to weather immediate negative impacts at the onset of the GFC of 2008-9. The continued availability of financial resources from non-traditional development partners and buoyant private capital flows at backdrop of the "Africa Rising" narratives also accorded resource-poor countries, especially frontier countries, a space to adopt counter-cyclical fiscal and monetary policy in the initial post Crisis period, while a number of fragile and postconflict countries lacked resources to implement such policies on their own. ${ }^{14}$ However, led by the dramatic fall of oil prices, the commodity price index across board has plummeted since mid-2014. This produced a sharp decline in SSA's Terms of Trade (TOT) and curtailed significantly the ability of the governments to maintain their counter cyclical policy stance. Oil and mineral exporting countries have started experiencing considerable strains in internal and external balances as well as sharp depreciation of their currencies. Several of them, including Ghana, had to turn to the IMF for its standard stabilisation package amid the fiscal and the debt crisis reemerging.

This recent episode reaffirms the huge challenge facing African countries in implementing counter-cyclical stabilisation policy over commodity price cycles, in particular when they are hit by large negative shocks. In fact, success in countercyclical policies demands a high degree of fiscal discipline and institutional set-ups and capacity to manage resource rents over price cycles. ${ }^{15}$ For low-income, resource-poor countries, it is urgent to establish a global innovative facility, which guarantees an automatic access to financial assistance without policy conditionality, so that they could conduct counter-cyclical demand management to mitigate negative impacts of external shocks. ${ }^{16}$ An application of sharp contractionary measures to curtail indiscriminately aggregate demand, which jeopardise long-term development goals, is hardly justifiable in low -income economies.

In this context, we make a strong case that a resolution of the short-run trade-off between the two objectives should be sought by pursuing macroeconomic management with a two-pillar policy stance on enhancing both aggregate effective demand and supply capacities over time and through economic cycles. That is, first, macroeconomic policies should be explicitly designed to increase aggregate demand along an equitable growth path to engender a pro-poor, shared growth. Second, they should be designed to sustain pro-investment macro conditions throughout cycles, so

\footnotetext{
${ }^{13}$ See, for example, Kasekende et.al, (2010).

${ }^{14}$ Kasekende et al (2010) cite Angola, Botswana and Nigeria among oil exporting countries, which used reserves to cushion the initial impacts of the GFC. A number o frontier economies such as South Africa, Mauritius and Kenya implemented fiscal expansion.

${ }^{15}$ For example, see Chile's more successful experience. It adopted Structural Fiscal Balance policy in 2001 with a view to developing a cyclically-neutral fiscal policy, where current expenditure is stabilized by linking to the structural level of fiscal income (Ffrench-Davis, 2010)

${ }^{16}$ See Nissanke and Kuleshov (2013) for detailed proposals for the innovative global facilities involving incentive-compatible aid and debt contracts.
} 
This is the accepted version of an article that has been published by Elsevier in Structural Change and Economic Dynamics on 18 Aug 2018. Published version available from:

https://doi.org/10.1016/i.strueco.2018.07.005

Accepted version made available under CC-BY-NC-ND 4.0 International License from SOAS Research Online: http://eprints.soas.ac.uk/26304/

that supply constraints could be reduced in combination with other policy tools that aim at building an economy's productive and absorptive capacity. Naturally, increasing aggregate demand and supply capacity is at heart of what economic development is about. However, in our view these policy commitments are also highly relevant to serving the stabilisation needs.

Here, two justifications can be offered in support of our propositions: i) macroeconomic stabilisation as conceived by Keynes entails, above all, the sustaining aggregate demand close to a full employment level throughout business cycles. For developing countries with abundant unemployed resources, this implies policies aiming at enhancing aggregate demand over time and sustaining efforts over cycles: ii) Combined with market excess created by euphoria at the advent of boom, developing economies experience overheating resulting from excess in aggregate demand over supply often due to sector-specific bottlenecks at the supply side and inadequate absorptive capacity at large. ${ }^{17}$ Hence, the focus on increasing supply and absorptive capacity can constitute an important stabilisation policy. Given limited resources, it is vital to coordinate investments to address critical supply constraints selectively and sequentially. This can be achieved if all policies are placed in a unified development strategic plan, wherein the two objectives are given due attention in an integrated manner. ${ }^{18}$ Stabilisation is then addressed through operationalised action plans in coordination with other policy tools, specifically with reference to medium- to long-term development objectives.

Admittedly, it takes a long lead-time for supply constraints to be addressed, because both sector-specific and economy-wide productive investments involve a considerable gestation period. Meanwhile, excess demand over supply in key sectors can give rise to high inflation environments that require short-run stabilisation measures. However, an application of standard stabilisation entailing a severe suppression of aggregate demand would not be effective in arresting the inflation trends arising from supply constraints. Cost-push inflation led by high food prices prevalent in many developing countries is a case in point, as discussed below in Section 3.2.1. Instead, by focusing on increasing aggregate demand and supply capacity firmly as a guiding principle, short-run stabilisation measures should be conducted counter-cyclically to sources of instability, and applied primarily to tame market excess by prudential regulatory measures. Accepting our propositions necessitate a radical mindset shift in macroeconomic policy making, calling for challenging the conventional policy making as molded over the last four decades or so, as detailed in 2.2 below.

\subsection{Cross-cutting Agenda for Macroeconomic Policies}

\footnotetext{
${ }^{17}$ See Nissanke (2010c).

${ }^{18}$ Botswana has conducted countercyclical stabilisation policies in the planning framework since independence. Partly thanks to the uniqueness of its main export commodity, diamond, it was much less exposed to large negative shocks and avoided the debt crisis, and the heavy dose of the SAPs, which made it possible to maintain its successive National Development Plans as a system of guiding its socio-economic development. Botswana's success story is often attributed to its developmental institutions (Robinson and Persons, 2006) and highly praised macroeconomic management, though it has been rather slow in diversifying its economic structures.
} 
This is the accepted version of an article that has been published by Elsevier in Structural Change and Economic Dynamics on 18 Aug 2018. Published version available from:

https://doi.org/10.1016/i.strueco.2018.07.005

Accepted version made available under CC-BY-NC-ND 4.0 International License from SOAS Research Online: http://eprints.soas.ac.uk/26304/

Set in the proposed framework, macroeconomic policy should address agenda transcending across several policy instruments. These cross-cutting agenda are interrelated, requiring a balancing act and a strategic use of instruments. We discuss them under five headings as indicated in Fig.2.

1) Scaling up public investments and public goods provision in a fiscal sustainable manner with a view to changing Africa's revealed comparative advantages

Africa at its stage of development requires a "big push" - a surge in productive investments at nation-state, region and continent levels for reducing large deficits in human resources and infrastructure, and inducing a change to Africa's revealed comparative advantage in the shortest possible time frame. In particular, an initial scaling up public investment is required to create positive externalities and address other forms of market failures. Without committed public investments, private investments would not come on board on a self-sustained basis to create opportunities and jobs for growing young population in an all-inclusive manner. Hence, macroeconomic policies should be consistently pro-public investment and pro-public goods provision towards building a foundation for a well-articulated, diversified economy and an inclusive society. Naturally, such a scaling up should be conducted in a financially sustainable manner, for which building a solid institutional foundation takes a primacy, as discussed below. Further, the scaling up should be planned in light of an economy's absorptive capacity, which itself should increase as a country starts reaping returns from productive investments.

2) Coordinating investment by embedding macroeconomic policy alongside other policies in a long-term development planning framework

Public investment using scarce resources should be made selectively, sequenced purposely, directed towards achieving the highest social and societal returns, i.e. the highest developmental dividends in the long run. For this, overall investment activities, both public and private, should be well coordinated across sectors in a big push with aggregate demand spillovers to facilitate "a move from a bad to a good equilibrium" (Murphy et. al (1989). Markets as institutions are characterized by coordinaten failure if left to their own device. One of the main functions of the strategic planning framework is to coordinate investments in a big push. Therein, the core remit of macroeconomic policies is to deliver pro-investment macro conditions so that a host of other policies could address key supply constraints sequentially and in coordination with each other. For this to happen all macroeconomic tools- fiscal, monetary and financial policies - should be pursued in an internally consistent and mutually reinforcing manner in support of other policy tools. This requires developing a solid institutional capacity for coordination on the part of the government and public agencies. For market failure in coordination by itself cannot preclude a possibility of coordination failure on the part of public agencies.

Now, for articulated economic structures to emerge in Africa, it is necessary to surpass a critical minimum threshold of the market size so that spatial externalities and agglomeration effects to take hold. Currently, the size of home market of most African 
This is the accepted version of an article that has been published by Elsevier in Structural Change and Economic Dynamics on 18 Aug 2018. Published version available from:

https://doi.org/10.1016/i.strueco.2018.07.005

Accepted version made available under CC-BY-NC-ND 4.0 International License from SOAS Research Online: http://eprints.soas.ac.uk/26304/

countries individually is too small, largely due to the low level of per capita income, while 20 countries are also small in its population with less than 6 million. The small size of the domestic market poses a real impediment to building an articulated economy with dynamic externalities and spillovers on the basis of scale economies required for high-value added activities. Therefore, regional integration is a logical option to follow, as larger regional markets would present each member country with the potential of a real 'win-win' outcome from the formation of common markets and internal demand spillovers. Regional cooperation and policy coordination is vital so that Africa could enlarge market sizes collectively on the basis of augmented effective aggregate demand from rising per-capita income and consumption spillovers.

\section{3) Maintaining macro stability for forward-looking investments through alleviating supply bottlenecks and taming market excess}

Structural transformation cannot be realized by public investments alone. Public investment is necessity for public goods provision as well as a means to animate private actors and crowd-in larger private investment. Private agents are strategic actors and partners to advance structural transformation. To entice rigorous private investment, maintaining macroeconomic stability is essential. Unstable macro conditions generate high uncertainty and risks, which would prevent private agents from making forwardlooking productive investments. At the same time harsh fiscal retrenchments and overly restrictive monetary policies, aimed at attaining 'macro stability' at almost any cost, is not capable of advancing the transformation agenda. A fresh approach to attaining stabilisation is imperative.

As stated earlier, in the traditional Keynesian paradigm, pursuing stabilisation is meant to be a carefully treading the short-run trade-off between the growth and stabilisation objectives. In navigating a dynamic path to achieve macroeconomic balances in the short-run, the rule advanced by Jan Tinbergen was used to be the first reference point in macroeconomic policy making. It postulates that policy makers require the same number of policy instruments as policy targets. ${ }^{19}$ Yet, the stagflation episode of the 1970s gave rise to the 'New Classical Counter Revolution' in macroeconomics. Macroeconomic policy making based on the Keynesian models was replaced with the one built on the 'microfounded macromodels' that incorporate 'rational expectations', the 'expectations-augmented Philips curve' and other restrictive assumptions such as the efficient market hypothesis and 'optimizing agents'. ${ }^{20}$ The 'real business cycle theory' emerged from this class of macromodels postulates that economic cycles are attributable only to technology shocks, not to aggregate demand fluctuations. Given this, macroeconomic management is claimed to tame the business cycle by containing inflation and stabilising output, but not to raise the output level over time. ${ }^{21}$ Price

\footnotetext{
${ }^{19}$ This thesis is further popularlised in the Swan diagram that is used to be the standard tool-kit in macroeconomic management of a Keynesian tradition.

${ }^{20}$ See Vines and Wills (2018) and Wren-Lewis (2018).

${ }^{21}$ See Blanchard and Summers (2017) for a summary of the evolution of macroeconomic policy thinking since the 1970s. Vines and Wills (2018) offer a useful contour of the evolution of macroeconomic
} 
This is the accepted version of an article that has been published by Elsevier in Structural Change and Economic Dynamics on 18 Aug 2018. Published version available from:

https://doi.org/10.1016/i.strueco.2018.07.005

Accepted version made available under CC-BY-NC-ND 4.0 International License from SOAS Research Online: http://eprints.soas.ac.uk/26304/

stability has become almost a synonym with macro stability, and monetary policy has been given a primacy over fiscal policy in macroeconomic management.

However, more recently, this 'microfoundation hegemony' in macroeconomics has been subject to scrutiny. The exclusive use of one single monetary policy instrument for stabilisation as in the case of the Inflation Targeting regime, had to be critically reappraised as an afterthought of the GFC of 2008-9. ${ }^{22}$ In its immediate aftermath, policy makers globally were forced to resort to a large fiscal stimulus package to attenuate the impact of the GFC and save the global economy from descending into a deep depression. However counter arguments against the use of fiscal stimulus were launched almost straightway in favour of fiscal austerity and debt stabilisation. ${ }^{23}$ Yet, the extended period of weak recovery from the GFC, now increasingly referred to as the Great Recession, has again led to another round of the academic debates on macroeconomic theory and policy. ${ }^{24}$

Drawing attention to the prolonged recessionary environments stuck in the "secure stagnation" equilibrium characterized by low output-productivity growth as well as low inflation, low interest rates and stagnant real wages coupled with the lower bound on nominal interest rates in advanced economies, a growing number of macroeconomists challenge the pre-crisis consensus, i.e. the exclusive use of monetary policy for stabilisation purpose as practiced before the GFC. They suggest: i) fiscal policy should be given a much more active role in stabilisation; ii) debt consolidation should take place more slowly and the discussion of debt sustainability must be revisited; and iii) there is a strong case for increased debt-financed public investment. ${ }^{25}$

Our quick excursion of the academic debates unfolded in macroeconomic theory and policy making since the 1970s attests the risk of uncritically basing macroeconomic management of developing economies on the theories and policymaking rules advanced for developed economies. To start with, macroeconomic theory was first conceived from the necessity to minimise short run fluctuations of economic activities of developed economies, not to 'raise output level over time'. Further, even this shortrun mission has been confined narrowly to the one aiming at price stability at the cost of downplaying the need for sustaining aggregate demand over business cycles. This dominant thinking in macroeconomics prevailed before the GFC has been inevitably challenged, since it failed not only in crisis prevention but also in effecting crisis management to steer economies out of the Great Recession.

theory since the 1930s and discuss the future directions in macroeconomic model building beyond the benchmark DSGE model.

22 See our discussion in Section 3.2 below.

23. This was played out in the heated debates over the direction of causality in the debt-growth nexus between Krugman as a prominent Keynesian and Rogoff and Reinhurt in the opposing camp.

${ }^{24}$ See Stiglitz (2014), Blanchard and Summers (2017) and the papers included in the special issues of Oxford Review of Economic Policy on "rebuilding macroeconomic theory", Volume 34, No.1-2.

${ }^{25}$ Blanchard and Summers (2017). 
This is the accepted version of an article that has been published by Elsevier in Structural Change and Economic Dynamics on 18 Aug 2018. Published version available from:

https://doi.org/10.1016/i.strueco.2018.07.005

Accepted version made available under CC-BY-NC-ND 4.0 International License from SOAS Research Online: http://eprints.soas.ac.uk/26304/

In developing countries, tasks assigned to macroeconomic management are even more demanding than just aggregate demand management aiming at stabilizing output over business cycles as in developed economies. As discussed earlier, macroeconomic policies for structural transformation should accomplish two objectives of stabilisation and development simultaneously. This calls for a radical change in mindset regarding how to go about making macroeconomic management to overcome disjuncture between the two objectives. In this context, we emphasised above the need to focus on comprehensive measures that could enhance aggregate demand and aggregate supply capacity over time and through cycles. With a skillful application of all macroeconomic policy tools in a coherent manner, stabilisation policies should focus on taming excess in market forces by prudential regulations and other policies with a view to reducing high volatility associated with speculation that engender more uncertain environments. What is needed is a development-focused approach to stabilisation, which could contribute to, rather than backtrack, structural transformation agenda.

4) Mobilising resources from stable sources for development finance and reducing aid dependence over time

The scaling up of productive investments requires stable financial resources of considerable size. In this context, newly available financial instruments for mobilizing private savings have attracted attention as source for financing Africa's development, in particular for closing its vast infrastructure gap. Among them, there are instruments specially targeted at global investors who can bear high currency and country risks in their quest for very higher returns, including sovereign bonds in hard currencies, private equity funds or other vehicles. ${ }^{26} \mathrm{~A}$ dozen countries have issued sovereign bonds in international capital markets since 2007 for financing infrastructure development or refinancing. ${ }^{27}$ Private Equity Funds (PEFs) with access to a variety of resources held by private or institutional investors operating globally have also become active in countries such as South Africa, Nigeria, Ghana and Kenya.

Though these new opportunities have been embraced with enthusiasm in Africa, a careful appraisal is due whether they are suitable as development finance at this stage of African development. ${ }^{28}$ For example, not only do bonds issued in hard currencies carry considerable currency risk, but they are much more expensive compared with concessional borrowing in yields, spreads and other contractual terms. Further, among debt instruments, bonds can be more expensive for infrastructure financing compared with loan contracts tailored for specific projects. Although the cost at the time of issuing was not viewed as prohibitively high under the historically low interest rates prevailed globally, there is always a risk of escalating costs, as soon as interest rates start edging

\footnotetext{
${ }^{26}$ See Beck et al. (2011).

${ }^{27}$ Ghana's sovereign bond issue of $\$ 750$ million in 2007 for financing energy and infrastructure projects attracted lots of publicity at the time. This enticed other countries such as Senegal, Tanzania, Zambia, Rwanda and Kenya to follow. Yet it is worth noting Ghana had to go back for refinancing its original bonds.

28 Equally, a careful assessment is required before embracing uncritically the use of 'blended finance' as development finance, which has been strongly advocated by the donor community more recently.
} 
This is the accepted version of an article that has been published by Elsevier in Structural Change and Economic Dynamics on 18 Aug 2018. Published version available from:

https://doi.org/10.1016/i.strueco.2018.07.005

Accepted version made available under CC-BY-NC-ND 4.0 International License from SOAS Research Online: http://eprints.soas.ac.uk/26304/

up and investors' risk appetites shift abruptly. Therefore, raising funds through sovereign bonds issues in international markets carries high risks and costs (currency risk, refinancing risk and interest rate risk among others). The history of sovereign debt restructuring processes is littered with difficult and costly negotiations, and orderly workout mechanisms are yet to establish. Restructuring sovereign bonds with private holders can be a lengthy and costly exercise at times of payment difficulties. Further, global investors participating in PEFs demand some of the highest risk premium for investing in Africa due to high-risk perception. In the process, they can make asset prices unrealistically high by competitive bidding in relation to returns that could be reasonably expected from real investments.

Hence, development finance should be vigorously sought first from more stable sources of funding by tapping domestic savings or overseas investors firmly committed to African development such as SWFs or remittances or diaspora's contributions to development finance. ${ }^{29}$ For this, as discussed later in Section 3.2, it is necessary to have financial policies in place to entice domestic financial institutions and markets to overcome their operational hindrances and serve as a reliable source of development finance.

Turning to sources for financing public investment, it is critical to develop and secure a stable domestic revenue base. Foreign aid flows to Africa have been very volatile and unpredictable. Further, the past experiences show that aid is often made available with a set of intrusive 'policy conditionality' that reduce the space of 'home-grown' policy making. Public finance cannot be overly dependent chronically on foreign aid. In the past, many African countries have suffered from a rather unhealthy "aid-dependence" syndrome that is detrimental to their 'nation-state' building efforts. ${ }^{30}$ Though fragile, post-conflict countries would remain aid-dependent for their budgetary operations for foreseeable future, it is high time for many African countries to plan a concrete path leading to graduation from aid dependence, by consolidating their own domestic and regional revenue basis through building a robust tax system and arresting illicit financial outflows.

\section{5) Securing fiscal sustainability by establishing fiscal legitimacy through institutional transformation}

Securing fiscal sustainability takes primacy in attaining both developmental and stabilisation objectives. The surge in public expenditure and investment cannot be planned and implemented in a fiscally fragile environment. An escalation of fiscal deficits in an unsustainable manner would results in macro instability that would undermine efforts to sustain productive investments. There is an urgency to develop the capacity of prudent and efficient public finance management. Furthermore, the transformation of economic structures and social orders requires a specific institutional

\footnotetext{
${ }^{29}$ According to World Bank (2014), 1) diaspora saving from SSA reached US\$37 billion in 2012; 2) officially recorded remittance flows to SSA was US $\$ 32$ billion in 2013, Nigeria alone accounting for US \$21 billion.

${ }^{30}$ See Nissanke (2010b) and Nissanke and Shimomura (2013).
} 
This is the accepted version of an article that has been published by Elsevier in Structural Change and Economic Dynamics on 18 Aug 2018. Published version available from:

https://doi.org/10.1016/i.strueco.2018.07.005

Accepted version made available under CC-BY-NC-ND 4.0 International License from SOAS Research Online: http://eprints.soas.ac.uk/26304/

configuration. In particular, for advancing Africa's ambitious transformation agenda, a strong coalition between the government and domestic stakeholders/actors is essential. In fact, a country's institutional configuration is the outcome of the intense publicprivate interface as political and economic institutions interact. ${ }^{31}$

In this specific context, we argue that fiscal sustainability can be truly secured in a medium- to long-run, when fiscal legitimacy is firmly built on the basis of strategic interplays between the government and private agents for development through creating a virtuous circle in the public goods provision-taxation nexus, as discussed below. The scaling up of public investments and public goods provision requires a consolidation of tax revenues on a stable basis. This could be achieved when private agents are assured that their government is accountable to them and it serves their collective interests. For this, the quality of governance at all levels of public institutions should be significantly improved by rooting out corruptive practices that have led to large scale illicit financial outflows from the continent to date. In short, Africa requires institutional transformation towards building a developmental nation-state, which keenly recognises the centrality of the taxation-public goods provision nexus for realizing its vision of transformation of economic and social structures.

\section{Making Macroeconomic Policies Work for Structural Transformation}

\subsection{Achieving Fiscal Sustainability by Establishing Legitimacy- An Institutional Analysis of Fiscal Policies}

Building robust institutions for distribution, coordination, collective action and conflict resolution as a nation state is of critical importance for advancing Africa's transformation agenda. How fiscal policy is conducted makes an enormous difference to the process of a nation-state building, as fiscal instruments do serve as an essential institutional conduit for resource allocation to address issues regarding distribution, redistribution and conflict resolution as well as for mobilizing resources as collective action. That is, through fiscal policy action, a government fulfills its pivotal dual role of providing public goods on the expenditure side and mobilizing resources through consolidating a tax system on the revenue side. As such, the public goods provisiontaxation nexus constitutes an implicit unified social contract between the government and domestic stakeholders.

Whilst macroeconomic policy discourses are often conducted with reference only to the state of fiscal balances in $\underline{\text { net }}$ for evaluating fiscal performances, an integrated approach to the two sides of fiscal balances - revenue and expenditure- is required to shed a light on how to make fiscal policy conducive to structural transformation. In this context, an agency-theoretic analysis discusses how the public-private interface can evolve through the fiscal policy space. For example, defining a government as a strategic agent maximizing its fiscal revenues, Aoki et al. (1996: 17) note that "whether government chooses to act as a predator or as a promoter of the private sector depends critically on the quality of its tax apparatus.... A revenue-maximising government with

\footnotetext{
${ }^{31}$ See Nissanke (2017a)
} 
This is the accepted version of an article that has been published by Elsevier in Structural Change and Economic Dynamics on 18 Aug 2018. Published version available from:

https://doi.org/10.1016/i.strueco.2018.07.005

Accepted version made available under CC-BY-NC-ND 4.0 International License from SOAS Research Online: http://eprints.soas.ac.uk/26304/

a poor tax apparatus will always choose to act as a predator". He suggests that in order to restrain government from acting as a predator, a nation state should be equipped with a high-quality tax collection apparatus and an information-processing capability. Otherwise, with their weak tax base, a predatory state holds up private agents to extract extra income as much as possible from them. ${ }^{32}$ In response to such government behaviour, private firms and rural households refrain from making risky but high return investments on their own unless assured that they can keep a substantial portion of returns.

At the expenditure side, if divisive instruments such as subsidies or preferential credits are used just as mechanisms to buy political support or to appease various interest groups, governments could become hostage to their narrow political support base. This is typically observed in a collusive state, wherein the government colludes with particular private agents for its advantage (Aoki, 2001, Chapter 6). Over time divisible benefits distributed to finance political costs could constitute a heavy burden on public finance. Distributive conflicts, though inherent in any society, can be exacerbated in this kind of state by the proliferation of patron-client relationships and patronage arising from the perverse use of fiscal instruments in such a manner. There is a risk of descending to predatory states.

Aoki's thesis may help explain some of the fiscal impasses observed in Africa. Politicians sitting in autocratic governments of natural resource-rich countries may have lacked the incentive to develop an efficient tax system for engaging with domestic stakeholders, as they could access resource rents to their personal benefits in nontransparent dealings with foreign oil or mining companies. Further, African governments in the early decades were criticized for their urban bias in public expenditures at the cost of agricultural development and their failure to undertake propoor investment in rural areas. This is in a contrast to the earlier experiences of several East Asian economies, where the pro-poor pattern of public expenditure in favour of the rural poor together with redistribution of productive assets such as land at early stages of development produced the 'shared' growth process for some time before globalization forces have given rise to growing inequality. ${ }^{33}$ The IFI-sponsored SAPs in the 1980s and 1990s, which were supposed to address Africa's previous institutional gridlocks, left governments with drastically reduced resources and capabilities, dysfunctional as an effective provider of essential public goods to domestic stakeholders.

The absence of reliable provision of public goods kept a significant proportion of private agents away from the "official" economy. The largely informal economy leading to a weak and narrow tax base reinforced the fiscal fragility. Thus, the poor provision of public goods and the fragile fiscal condition kept its own loop of vicious

\footnotetext{
${ }^{32}$ In Aoki (2001 and 2007), a government is defined as a strategic player of the game in the political domain under the rule of the game, i.e. institutions. In contrast, a state is defined as "a stable order of relationships between the government and private agents in the political domain". He suggests different prototypes of the "state" exist, such as democratic, collusive and predatory.

${ }^{33}$ See Nissanke and Thorbecke (2008 and 2010) for more discussions.
} 
This is the accepted version of an article that has been published by Elsevier in Structural Change and Economic Dynamics on 18 Aug 2018. Published version available from:

https://doi.org/10.1016/i.strueco.2018.07.005

Accepted version made available under CC-BY-NC-ND 4.0 International License from SOAS Research Online: http://eprints.soas.ac.uk/26304/

circle of condemning the economy to a low equilibrium, leading to a fragile state with a reduced institutional capability to function. Fiscal fragility accompanied by sharp retrenchments is known to aggravate distributional tensions and conflicts in a society fractured along ethnical and/or linguistic lines. Therefore, without attending to such an institutional trap, little progress could be made in nation-state building through mobilising energy and resources of people for commonly shared developmental objectives. Democracy cannot work in an institutional vacuum. As Aoki (2001) notes, institutional configurations for supporting the democratic state as a stable selfenforcing equilibrium can emerge only through active interface between the government and private agents/domestic stakeholders.

It is imperative, from this institutional perspective, to secure fiscal sustainability and legitimacy by engaging with domestic stakeholders through high quality public goods provision while building a solid domestic revenue base. This would in turn bring about double dividends: i) breaking out from the vicious circle of fiscal fragility, resulting from the cumulative causation of poor public goods provision and a weak tax base; and ii) building an institutional foundation for transparency and accountability in public finance management towards domestic stakeholders. With increased credibility in providing public goods and undertaking rigorous investments in basic economic and social infrastructures, underpinned with prudent and disciplined management of public resources, domestic stakeholder's readiness to contribute towards tax revenues would increase.

What is required is a solid institutionalised fiscal mechanism for productive dialogues between policy-makers and domestic stakeholders with a view to enhancing collective efforts in building a developmental state whilst creating a diversified portfolio of productive assets. The historically observed high dependence of African governments on foreign aid for their development finance and policy formation has seriously undermined the progress toward building a developmental 'nation state' as a facilitator of structural transformation. To trigger the process of virtuous circle, aid should be made available for developing a home-grown institutional configuration conducive to structural transformation without intrusive policy conditionality. ${ }^{34}$

In short, the issues of fiscal sustainability should be examined by taking an integrated approach to both sides of fiscal balance. This means establishing fiscal legitimacy in the eyes of domestic stakeholders. The majority of stakeholders in Africa are the voiceless poor, who can be brought effectively into a country's developmental mission, only if they are assured of a fair and transparent fiscal mechanism of distributing rents for advancing their socio-economic needs. Towards this end, fiscal policies should aim at: 1) broadening domestic revenue bases with enhanced and sustained provision of high quality public goods so that domestic stakeholders feel tangible returns from their tax contributions to fiscal revenue; 2) enhancing tax revenues through improved governance to stem cross border illicit financial flows and strengthening negotiating positions with transnational corporations and foreign investors in interests of domestic

\footnotetext{
${ }^{34}$ See Nissanke and Shimomura (2013) discuss the role of aid as handmaiden for institutional development.
} 
This is the accepted version of an article that has been published by Elsevier in Structural Change and Economic Dynamics on 18 Aug 2018. Published version available from:

https://doi.org/10.1016/i.strueco.2018.07.005

Accepted version made available under CC-BY-NC-ND 4.0 International License from SOAS Research Online: http://eprints.soas.ac.uk/26304/

stakeholders; 3) having a clear roadmap of how to change Africa's revealed comparative advantage by turning natural resource wealth into productive assets through pro-poor fiscal expenditures; and 4) establishing a counter-cyclical intertemporal allocation of resource rents and sovereign debt management embedded in a well-run system of public finance management with transparency and accountability to all parties. ${ }^{35}$

\subsection{Making Monetary and Financial Policies Conducive to Africa's Structural Transformation Agenda}

3.2.1 Reappraisal of Contemporary Discourse on the Monetary Policy Regime in Arica's context

Given the monetary policy dominance in macroeconomic management where achieving price stability is seen as its sole purpose, the scope of conventional monetary policy discourses has become narrow, with a focus on the choice between the two regimes - the aggregate monetary targeting and the inflation targeting (IT). Reflecting the dominant literature in monetary policy conducts for some time, manifesting in the pronouncement of the 'Great Moderation' by Bernanke in 2004 to mark the achievement of reducing the volatility of business cycle fluctuations, it was claimed before the GFC that the efficacy of macroeconomic management is almost exclusively found in the adoption of the IT regime as a universal solution for ensuring macro stability.

The IT has gained popularity worldwide as a superior regime for its simplicity: there is only a single target and a single instrument - the interest rate. The rule-based decisionmaking under the IT regime is thought of overcoming 'time inconsistency' problem arising out of dynamic interface/feedback loops between policies and private agents' expectations. This property is presumed to allow simpler communication to the public, because the IT regime is seen to provide a credible, rule-based anchor in formation of inflation expectation of agents operating in financial markets. The IT regime is claimed to provide a single "magic wand" for ensuring macro stability by reducing volatility in both output and inflation rate. ${ }^{36}$

Central banks in Africa have long used reserve-money programmes for their monetary policy in which the balance sheet operations are the instrument, whilst the base money is the operational target and broader monetary aggregates as their intermediate targets. Recently, however, many central bankers have been attracted to the IT regime and its rule-based simplicity. South Africa was the first to adopt it. With the IMF's technical support, others such as Ghana and Kenya, where there are relatively deeper financial markets - a precondition for a successful operation of the IT regime - followed suit. However, a question remains whether the IT regime is appropriate as a single instrument for achieving macro stability, let alone the twin objectives of stabilisation

\footnotetext{
35 See Nissanke (2014) for detailed discussions on these measures.

${ }^{36}$ There are some variations in the mandate given to the Central Bank as well as in its operation. Central banks of emerging market economies such as Brazil have instituted an "exit" route of discretionary nature in the light of a greater effect of exchange rate movements on monetary stability, without having the exchange rate as a target.
} 
This is the accepted version of an article that has been published by Elsevier in Structural Change and Economic Dynamics on 18 Aug 2018. Published version available from:

https://doi.org/10.1016/i.strueco.2018.07.005

Accepted version made available under CC-BY-NC-ND 4.0 International License from SOAS Research Online: http://eprints.soas.ac.uk/26304/

and development. Importantly, the suitability and effectiveness of the IT regime is not discussed in the light of the predominant nature of inflation in Africa- the cost-push inflation, which has disproportionately large effects on the livelihood of both the rural and the urban poor.

Meanwhile, the onset of the GFC forced a critical evaluation of the original version of the IT regime for its failure to detect the fragility developing in financial systems and markets. This has led to a post-crisis consensus, suggesting: 1) the list of targets must include financial stability, in addition to macro stability; 2) the single policy rate instrument cannot achieve both targets - financial and monetary stability; and 3) the link between inflation stability and the output gap is much less tight than previously assumed. Hence, the policy rate cannot achieve macro stability, as it cannot reduce volatility in output as well as in prices. ${ }^{37}$ Clearly, the central banks should not be content with a single-minded focus on keeping inflation stable but in engaging with the question how to make sure that inflation target is not pursued at cost of low growth and high unemployment.

As a result of reappraisal, the IT regime, which was seen a neat solution to macro stability before the GFC, has been evolving into a regime with multiple objectives and targets, on the one hand, and more policy tools, on the other, in the post-crisis debate. In addition, the central banks of advanced countries have been forced to resort to unconventional monetary policy tools such as the Quantitative Easing to overcome the Liquidity Trap. Indeed, trapped in the recession and stagnation since the GFC, most of the central banks are forced to keep policy rates near or below zero in order to emerge from recession or feeble growth.

If the IT regime is not a panacea in advanced economies, it cannot be a magic solution to multiple objectives facing developing countries. To begin with, neither the IT regime nor the aggregate monetary target regime could be a solution to cost-push inflation in developing countries where high inflation is not necessarily just a monetary phenomenon and often associated with escalating prices of basic wage goods such as food and fuel. ${ }^{38}$ The latter stems from domestic supply shocks or high import prices often following on large currency depreciations. Cost-push inflation of this kind requires policies that address supply-side factors such as crop failures or attend volatile currency movements in light of the high 'pass-through rate' from world prices to domestic inflation rates. Furthermore, in low-income economies, where capital markets are in their infancy, and the use of informal finance is widespread, the efficacy of conventional monetary instruments for controlling inflation is much less due to weaker transmission channels through formal financial systems.

Clearly, an appropriate policy regime cannot be sought in a simple emulation to the one that may have appeared to work elsewhere. If monetary policy is tightened in response

\footnotetext{
${ }^{37}$ See, for example, Blanchard (2012) and Blanchard and Summers (2017).

38 For example, Adam et.al (2012) show that headline inflation in Tanzania is largely driven by highly volatile agricultural outputs, caused by rain-fed nature of agriculture but exacerbated by spatially fragmented agricultural domestic markets and inadequate storage facilities.
} 
This is the accepted version of an article that has been published by Elsevier in Structural Change and Economic Dynamics on 18 Aug 2018. Published version available from:

https://doi.org/10.1016/i.strueco.2018.07.005

Accepted version made available under CC-BY-NC-ND 4.0 International License from SOAS Research Online: http://eprints.soas.ac.uk/26304/

to supply shocks that have inflationary consequences, a policy response entailing a contraction in aggregate demand is pro-cyclical. Such a stance runs the risk of worsening the economic impacts of negative shocks. Surely, a strict inflation targeting with an exclusive focus on maintaining low inflation and limiting the expansion of domestic credit is inappropriate in many cases, calling for alternative approaches, so that monetary policy can be pro-investment and pro-employment orientated, in support of Africa's structural transformation. ${ }^{39}$

\subsubsection{Positioning in a Space of Macroeconomic Policy Trilemma for Taming}

\section{Financial Excess}

Macro stability cannot be achieved by domestic monetary policy of any kind in its isolation in the context of 'small open economies', which are constantly exposed to large external shocks, both real and financial. Frequent abrupt TOT changes originating from commodity markets are the most significant real shocks for many African economies, while highly volatile exchange rates and cross-border capital flows characterized as 'hot money' can derail stabilisation efforts by overwhelming macroeconomic imbalances. The latter situation can be better illustrated with reference to the thesis of 'Macroeconomic Policy Trilemma', as shown in Fig.3. ${ }^{40}$ This proposition, which is also known as the Impossible Trinity thesis, can be used to evaluate explicitly the choice of the domestic monetary policy regime in conjunction with management of exchange rates and cross-border capital flows in a more integrated manner. It stipulates policymakers in open economies face a trilemma: whilst policymakers have three desirable objectives (exchange rate stability, free international capital mobility, and monetary policy independence to engage with domestic economic goals), they are forced to give up one objective, since only two out of the three can be mutually consistent. Resorting to this thesis, it has been argued that the only exchange rate regimes that remain viable in an era of free cross-border capital mobility are the two corner positions within the trinity, i.e. either pure floating or hard pegs, referred to as the two-corner view on the exchange rate regime. ${ }^{41}$

\section{-Insert Figure 3 about here-}

However, this dominant position is entirely driven by the imperative of financial globalisation, which itself has been questioned in the aftermath of the GFC. The arguments rest on the assumption that financial openness alone should not be challenged in the trinity, either because of the large benefits that financial openness is promised to produce, or because free capital mobility is inevitable due to changes in global technology, market structures or politics. While the thesis applies to any open economy, the policy

\footnotetext{
${ }^{39}$ For example, Heintz and Pollin (2008) suggest that given the relatively high thresholds at which inflation starts exerting negative effects on growth in developing economies, the excessive contractionary bias in monetary policies has stifled the growth of domestic firms and their ability to create gainful employments in Africa. In place of such monetary policies, they suggest adopting low short-term real interest rates as the operating targets of monetary policy as an employment-centered strategy.

${ }^{40}$ See Obstfeld (2015) for a recent exposition of this thesis.

41 It is also known as the hollowing out hypothesis or the bi-polar view.
} 
This is the accepted version of an article that has been published by Elsevier in Structural Change and Economic Dynamics on 18 Aug 2018. Published version available from:

https://doi.org/10.1016/i.strueco.2018.07.005

Accepted version made available under CC-BY-NC-ND 4.0 International License from SOAS Research Online: http://eprints.soas.ac.uk/26304/

constraint posed is particularly severe for developing countries, reflecting their disadvantaged position in global finance. Their domestically issued notes are 'soft' in currency hierarchy, acting as an additional source of fragility. Their central banks cannot act as a 'lender of last resort' at times of crises. ${ }^{42}$

Thus, the financial fragility of developing economies is related to their asymmetric position vis-à-vis advanced countries in international finance as well to their structural characteristics. As Bordo and Flandreau (2001) note, the degree of 'financial maturity' - the ability to issue international securities denominated in own currency - is a key factor in distinguishing 'core' countries from 'periphery' ones for exchange rate regime choices. The prevalence of their 'Fear of Floating' (Calvo and Reinhart, 2000) or 'the Case of Hard Pegs' (Calvo 2000) is also closely related to: i) liability dollarisation, i.e. the condition in which financial contracts are expressed in foreign currency; ii) fear of inflation due to the high pass-through coefficients (measurements of the speed of transmission of devaluation to inflation); and iii) their nascent capital markets. Despite the strong case made by many influential macroeconomists for the two-corner view, de facto intermediate regimes have proved the most prevailing in developing countries.

It is in this context, the IT-cum-pure floating regime, which has gained popularity, should be evaluated. It is argued: 1) the credibility of the commitment to the IT regime is assured by the institutional arrangements of the central bank's independence from political interferences and that this would ensure transparency and accountability for monetary stability; 2) this credible institutional commitment to the inflation targeting would provide a nominal anchor under a pure floating, superseding the argument for a fixed regime as a nominal anchor. That is, by adopting an IT regime and some variations of the Taylor Rule as a policy guide (Taylor 2001), the monetary stability is supposed to prevail under a pure floating system without having exchange rate-based stabilization in place. The popularity of the IT regime lies in the possibility of allowing to opt for a floating exchange rate regime in the context of the 'impossible trinity' in a world of free capital mobility.

However, the impossible trinity thesis by itself does not imply that full financial integration should be pursued at any cost. It merely suggests the difficulty in achieving all the three objectives. As Frankel (1999) suggests, in theory, countries could position anywhere within the triangle: they can opt for a half-independent monetary policy and a half-fixed exchange rate by adopting intermediate regimes such as a target zone; or they can have both an independent monetary policy and a stable or fixed exchange rate by imposing effective capital controls. The jury is still out on the question of an optimal combination of the exchange rate regime and the monetary policy regime under financial globalization. In practice, 'fear of floating' has been prevalent in developing countries, not only on account of the high 'pass-through rates' and the balance sheet effect as result of their increasing liability dollarization but also on account of frequent supply shocks and vulnerability to external shocks as in African countries.

42 Eichengreen and Hausmann (1999) suggest developing economies are handicapped by the 'original $\sin$ ' due to their incomplete domestic financial markets. 
This is the accepted version of an article that has been published by Elsevier in Structural Change and Economic Dynamics on 18 Aug 2018. Published version available from:

https://doi.org/10.1016/i.strueco.2018.07.005

Accepted version made available under CC-BY-NC-ND 4.0 International License from SOAS Research Online: http://eprints.soas.ac.uk/26304/

The dual role of exchange rate policy in managing both external and internal balances means a trade-off between flexibility and stability in the choice of the exchange rate regime. The real target approach to an appropriate exchange rate policy focuses on the developmental needs to keep competitiveness of tradable goods so as to ensure a viable and sustainable position in the current account, while the nominal anchor approach emphasizes the need to ensure monetary stability through keeping currency fluctuation limited. For many African countries, increasing the competitiveness of newly emerging tradable goods in both domestic and foreign markets and developing non-traditional exports is crucial in efforts to diversify trade structure away from the commoditydependence and the vulnerability associated with it. Indeed, it is in this context that Rodrik (2011) views the policy of undervalued currencies as a key developmental policy tools for structural transformation while eschewing both market and government failures.

As integration into international capital markets of African economies has recently intensified, policymakers should take a critical, forward-looking position in a number of the issues raised in the 'Trilemma' debate. In this context, it is important to take a note of the conclusion reached by Rey (2013) after examining the nature of international capital flows, engendering highly volatile global financial cycles. She suggests that the global financial cycle transforms the trilemma into a 'dilemma' or an 'irreconcilable duo': independent monetary policies are possible if and only if the capital account is managed. Indeed, both equity and debt flows are highly volatile and pro-cyclical, increasingly driven by global liquidity cycles, resulting in sudden 'surges and retrenchments' (Forbes and Warnock 2012). Thus, mediated through high frequency trading, portfolio flows are 'hot money', driven by fast shifting in global investors' liquidity preferences and risk appetites. Sudden changes in their selffulfilling expectations and market sentiment induce globally synchronised bubble-bust cycles in asset markets as well as credit conditions.

These all point to the importance for African policymakers to conduct monetary policy in conjunction of managing an exchange rate trajectory and cross-border capital flows in a dynamic country-specific context with a view to reducing external sources of monetary instability. Africa's structural transformation cannot be advanced when economies are exposed to additional financial shocks. It is necessary to monitor and screen cross-border capital flows on the basis of carefully weighing benefits and costs of different types of flows. ${ }^{43}$ Further, beyond cross-border capital flow management, well-run regulatory systems should be in place for overseeing activities in financial markets and institutions with a view to taming financial 'excess' for counter-cyclical stabilisation purposes. Prudential financial regulations, both micro and macro measures, are necessary for market-based systems to function without causing havoc in real economic activities periodically and prevent crisis from developing in the first place.

\footnotetext{
${ }^{43}$ After the GFC of 2008, there is a growing consensus that temporary capital controls are a legitimate part of the toolkit of macroeconomic management for developing economies (Ostry et al., 2010 and IMF 2012). In contrast, among others, Cooper (1999) argues for non-temporary controls on the importance of making the value of a country's currency free from speculative movements of private capital and reducing both nominal and real exchange rate variability.
} 
This is the accepted version of an article that has been published by Elsevier in Structural Change and Economic Dynamics on 18 Aug 2018. Published version available from:

https://doi.org/10.1016/i.strueco.2018.07.005

Accepted version made available under CC-BY-NC-ND 4.0 International License from SOAS Research Online: http://eprints.soas.ac.uk/26304/

\subsubsection{Securing Development Finance through strengthening domestic financial markets} and institutions

With increased cross-border capital flows, Africa's liability-assets positions with the rest of the world and its debt profile/dynamics have been changing significantly. If these flows are deployed in productive investment with significant growth dividends, the capacity of absorbing capital flows and debt carrying capacity of African economies could be enhanced. Yet, one should bear in mind that international capital flows under the contemporary financial globalization is more of diversification finance conducted through asset swapping for risk hedging and shedding by financial investors to achieve maximum risk-adjusted returns to asset holders than development finance as such.

Hence, rather than courting international investors excessively, policymakers' focus should be on deepening domestic financial markets and strengthening the capacity of local financial institutions with a view to enhancing their role in development finance provision. In parallel with developing forward markets for domestic currencies, issuing debt instruments in domestic currencies can provide a necessary 'learning' space, so that liquid bond markets to emerge with a capacity to trade long-dated debt instruments by offering appropriate term structures. Domestic bond markets can aim at local investors and financial institutions, and those with firm commitments and interests aligned with Africa's economic development such as diaspora. ${ }^{44}$ They are more willing to take currency risks or other country risks associated with local-currency denominated instruments with a longer maturity.

Naturally, developing their own deep, liquid markets are beyond the reach of smaller African countries. However, they can resort to regional capital markets in sub-regional 'hub' countries to serve their financial needs for infrastructure development or financing cross-border infrastructure projects through regional cooperation. A few 'frontier' markets economies have taken an initiative to cultivate domestic bond markets. For example, Kenya issued domestic bonds for infrastructure projects with a total value of US\$ 1 billion in 2009/2010. This has subsequently paved the way to issuance of corporate bonds by both private and state-owned companies, including Safaricom (a mobile phone company) and KenGen (an electricity utility company). Additional incentive schemes instituted in conjunction with infrastructure bonds in Kenya are to allow bond holders to use the infrastructure bonds as collateral for accessing bank loans while banks can pledge them as collateral for their operation. This example shows that one right initiative can have the potential of creating a multiplier effect in development finance provision.

In fact, the landscape of Africa's financial systems has recently undergone a notable change. African-wide financial integration has been taking place through an increasing number of cross-border banking with an entry of regional and continental banks. At the same time, there have been efforts to address the poor's access to financial services by the widespread diffusion of microfinance institutions (MFIs), and more recently micro insurances. The recent acceleration of 'financial inclusion' has also been facilitated

\footnotetext{
${ }^{44}$ Ethiopia, Kenya and Nigeria issued diaspora bonds for infrastructure financing.
} 
This is the accepted version of an article that has been published by Elsevier in Structural Change and Economic Dynamics on 18 Aug 2018. Published version available from:

https://doi.org/10.1016/i.strueco.2018.07.005

Accepted version made available under CC-BY-NC-ND 4.0 International License from SOAS Research Online: http://eprints.soas.ac.uk/26304/

with application of new technology such as mobile banking and money services for transfers, payments and saving. For example, Kenya's M-PESA has dramatically changed the modes of delivering financial services to low-income segments of population. Such mobile money services have now rapidly spread across Africa.

While the recent progress in deepening financial markets and widening financial services is encouraging, this by itself is not enough. Historical experiences of late industrialised countries such as Germany, Japan and others show that financial institutions as a system in different shades did make a pivotal contribution to their success in achieving structural transformation within a short time span in their catchingup processes. ${ }^{45}$ The pro-growth effects of finance are known to be greatest when economies are in the catching-up phase in their productivity levels with technology adoption and infusion. Finance is vital for unlocking production opportunities and providing support at critical stages of technology development and diffusion. Steady financial flows in support of productivity-enhancing investment and skill-technologyknowledge acquisition into new dynamically evolving activities are essential for facilitating structural transformation while securing inclusiveness ex ante in developmental processes. Thus, finance can potentially play a vital role in accelerating the pace of structural transformation by providing appropriately structured products for domestic firms' acquisition, adaptation and diffusion of technologies as well as the continuous development of their productive capabilities.

In Africa, however, structural transformation processes have been impeded by the paucity of financial services for meeting the need of real sector development and transformative agenda. While a continuum of financial products are under-supplied by financial systems, a 'missing middle' phenomenon in financial services should deserve more attention. The absence of financial institutions supporting productive investments and technological innovation of mid-sized enterprises may be particularly binding for facilitating transformation processes. Development of these enterprises is key for increasing value addition, technology acquisition, development and diffusion and their integration into global value chains and international trade. Critical financial gaps and mismatches are still acute and are hampering enterprise development, new and green technology diffusion and, ultimately, sustained economic growth. While secure working capital provision is critical for survival of SMEs, it is not sufficient for becoming a vehicle in their rapid expansionary paths.

Africa's banks, operating in environments characterized by high transaction costs and poor information flows, are still reluctant to extend loans to domestic firms, especially SMEs. The portfolios of most banks have been continuously dominated by 'excess liquidity', whereby banks prefer to hold assets predominantly in low risk-high return instruments with a short maturity such as treasury bills or central bank papers issued for a sterilization purpose. ${ }^{46}$ The high policy rates prevailing in Africa for controlling

\footnotetext{
45 For example, Aoki and Patrick (1994) and Teranishi (2000).

46. See Nissanke and Aryeetey (1998 and 2006) and Saxegaard (2006) for discussions on the excess liquidity conditions, including causes and consequences.
} 
This is the accepted version of an article that has been published by Elsevier in Structural Change and Economic Dynamics on 18 Aug 2018. Published version available from:

https://doi.org/10.1016/i.strueco.2018.07.005

Accepted version made available under CC-BY-NC-ND 4.0 International License from SOAS Research Online: http://eprints.soas.ac.uk/26304/

inflation or sterilisation purposes has led to de facto crowded-out loans to SMEs. The lack of changes in these conditions explains the paucity of savings mobilisation efforts by banks and the 'low-lending trap' in the presence of latent excess demand for credit and loans. Further, high transaction costs and fragmented financial markets have kept interest spreads between deposit and loan rates very high, and the cost of obtaining bank credits and loans are often prohibitively high for most domestic firms. These operational constraints should be addressed so that financial institutions would play a vital role in financial intermediation to their full potential. This prevailing condition also highlights the need for striking a better balance between the stabilisation and development objectives in conducting monetary policy so that domestic firms can have access to bank loans and credits at a reasonable cost, and their activities and investments are not starved off flows of funds.

\section{Concluding Remarks}

As a direct result of the interrelationships among macroeconomic frameworks, institutional configuration and development outcomes, the previously prevailed policy paradigms in sub-Saharan Africa failed to deliver structural transformation. Given the new landscape emerging at the backdrop of "Africa rising", Africa is positioned at a historical juncture with new opportunities as well as formidable challenges in advancing its historical agenda of structural transformation. ${ }^{47}$ Yet, the conventional macroeconomic policy discourse with an exclusive focus on maintaining macro stability in a low inflation environment is inadequate for the purpose of accelerating structural transformation of African economies. In the past, short-run stabilisation imperatives have largely driven practical agenda of macroeconomic management at the cost of suspending development efforts.

This 'think-piece' outlined an alternative macroeconomic framework, wherein a resolution of short-run trade-offs between the two macroeconomic policy objectivesstabilisation and development- can be sought. We presented a case that macroeconomic policies should be placed in a development-centered planned framework, which would provide an anchor for navigating a path towards structural transformation. We emphasized that macroeconomic management, including stabilisation policies, should be consistently pursued with a two-pillar policy stance on enhancing both aggregate effective demand and supply capacities over time and through cycles by sustaining a positive feedback loop in the investment-growth nexus. Macroeconomic policies should consistently engage with the question how to increase aggregate demand along an equitable growth path to engender a pro-poor, shared growth. At the same time, they should strive for providing continuously pro-investment macroeconomic conditions so that other policies could alleviate supply constraints by building an economy's productive and absorptive capacity.

It is impossible to sustain the process of structural transformation with shrinking aggregate demand. A prolonged application of contractionary policies in the name of 'stabilisation' is universally detrimental to development, as aggregate effective demand would contract sharply. There is no justification of maintaining 'austerity' stance if

\footnotetext{
${ }^{47}$ See Nissanke (2017b).
} 
This is the accepted version of an article that has been published by Elsevier in Structural Change and Economic Dynamics on 18 Aug 2018. Published version available from:

https://doi.org/10.1016/i.strueco.2018.07.005

Accepted version made available under CC-BY-NC-ND 4.0 International License from SOAS Research Online: http://eprints.soas.ac.uk/26304/

governments are equipped with a system of prudent public resource management while honestly engaged with structural transformation agenda. A disruption to the process of building productive and absorptive capacity should not be allowed in the name of stabilisation either. Instead, short-run stabilisation measures should be applied primarily to tame market excess by prudential regulations, exchange rate management and other policy tools, and conducted counter-cyclically to sources of instability and macro imbalances, correctly identified with a careful analytical assessment. Each of macroeconomic policy tools -fiscal, monetary and financial policies - should be executed in coordination so that they in aggregate could pursue the five cross-cutting policy agenda discussed in the paper. An appropriate policy regime cannot be found in a simple emulation to the one that may have appeared to work elsewhere. A radical shift of mindset, departing from the conventional macroeconomic policy debates, is required in our quest for alternative macroeconomic frameworks that can contribute to, rather than backtrack, Africa's structural transformation efforts.

\section{References}

Adam, C., D. Kwimbere, W. Mboe and S. O’Connell (2012), "Food Prices and Inflation in Tanzania", Working Paper No. 163, African Development Bank Group

African Development Bank Group (2017), Industrialize Africa: Strategies, Policies, Institutions and Financing, Abidjan, Côte d'Ivoire

Aoki, M. (2001), Towards a Comparative Institutional Analysis, The MIT Press

Aoki, M. (2007). 'Endogenizing institutions and institutional changes.' Journal of Institutional Economics. Vol.3, pp.1-31

Aoki, M and H. Patrick (eds) (1994), The Japanese Main Bank System, Oxford University Press

Beck, T., S.M. Maimbo, I. Faye and T. Triki (2011) Financing Africa: Through the Crisis and Beyond, Making Finance Work for Africa, African Development Bank

Blanchard, O (2012), "Monetary Policy in the Wake of the Crisis", in Blanchard O., D. Romer, M.Spence, and J.Stiglitz ed., In the Wake of the Crisis, IMF

Blanchard, O and L.Summers (2017), 'Rethinking Stabilization Policy. Back to the Future', paper presented at the "Rethinking macro policy" conference at the Peterson Institute for International Economics, October 2017

Bordo, M. and M. Flandreau (2001), Core, Periphery, Exchange Rate Regimes and Globalisation, paper presented at the NBER conference, "Globalisation in Historical Perspective", Santa Barbara, May 4-5, 2001

Calvo, G. A (2000): The Case for Hard Pegs in the Brave New World of Global Finance”, presented at the ABCDE Europe, Paris, June 2000

Calvo, G. A. and C. Reinhart (2002): Fear of Floating, Quarterly Journal of Economics 117 (May 2002), pp.379-408

Cooper, R (2019), “Should Capital Controls be Banished?”, Brooking Papers on Economic Activity, 19991. Issue 1 
This is the accepted version of an article that has been published by Elsevier in Structural Change and Economic Dynamics on 18 Aug 2018. Published version available from:

https://doi.org/10.1016/i.strueco.2018.07.005

Accepted version made available under CC-BY-NC-ND 4.0 International License from SOAS Research Online: http://eprints.soas.ac.uk/26304/

de Vries, Gaaitzen, Marcel Timmer, and Klass de Vries. 2015. "Structural Transformation in Africa: Static Gains, Dynamic Losses.” The Journal of Development Studies, Vol.51, Issue 6, 674-688

Eichengreen, B and R. Hausmann (1999), "Exchange Rates and Financial Fragility”, Pacific Basin Conference: Financial Crises in Emerging Markets, September, 1999

Forbes, K. J. and Francis E. Warnock (2012). "Capital Flow Waves: Surges, Stops, Flight, and Retrenchment.” Journal of International Economics 88(2): 235- 251

Frankel, J. (1999): No Single Currency Regime is Right for All Countries or At All Times", NBER Working Paper 7338, National Bureau of Economic Research, Cambridge MA.

Ffrench-Davis, R. (2010) 'Latin America: The Structural Fiscal Balance Policy in Chile: A Move Towards Counter-Cyclical Macroeconomics' Journal of Globalization and Development, Vol.1, Issue 1

Heintz, J and R. Pollin (2008), “Targeting Employment Expansion, Economic Growth and Development in Sub-Saharan Africa: Outlines of an Alternative Economic Programme for the Region", UN Economic Commission for Africa

IMF (2012) The Liberalization and Management of Capital Flows - An Institutional View, https://www.imf.org/external/np/pp/eng/2012/111412.pdf

Kasekende, L , Z. Brixova and L. Ndikumanna (2010), 'Africa: Africa's Counter-Cyclical Policy Responses to the Crisis', Journal of Globalization and Development, Vol. 1, Issue 1.

McMillan, M, and D. Rodrik. 2011. "Globalization, Structural Change and Productivity Growth.” In Making Globalization Socially Sustainable, eds. Marco Bacchetta and Marion Jansen, 49-84. Geneva: International Labour Organization

McMillan, M, D. Rodrik and I. Verduzco-Gallo (2014) "Globalization, Structural Change and Productivity Growth with an Update on Africa.” World Development Vol. 63, pp. 11-32.

Maizels, A (1992), Commodities in Crisis, Oxford, Clarendon Press

Murphy K. M., A. Shleifer and R. W. Vishny (1989),'Industrialization and the Big Push", The Journal of Political Economy, Vol. 97, Issues 5 (Oct., 1989), 1003-1026

Nissanke M. (2010a), "Issues and Challenges for Commodity Markets in the Global Economy: An Overview" Chapter 3 in M. Nissanke and G. Mavrotas (eds.), Commodities, Governance and Economic Development under Globalization, Palgrave/Macmillan Press

Nissanke M. (2010b), "Reconstructing the Aid Effectiveness Debate”, in G. Mavrotas ed, Foreign Aid for Development: Issues, Challenges, and the New Agenda" Oxford University Press

Nissanke M. (2010c), "Commodity Market Structures, Evolving Governance and Policy Issues"” Chapter 4 in M. Nissanke and G. Mavrotas (eds.), Commodities, Governance and Economic Development under Globalization, Palgrave/Macmillan Press

Nissanke, M (2014), “ Macroeconomic Framework for Structural Transformation of African Economies', commissioned by the UNECA, as the single background paper for the UN ECA Report under the title, Macroeconomic Policy and Structural Transformation, March 2016, Addis Ababa: United Nations Economic Commission for Africa (UNECA)

Nissanke, M (2017a), 'A Quest for Institutional Foundations towards Inclusive Development in SubSaharan Africa', Chapter 12 in Poverty Reduction in the Course of African Development, ed. by M.Nissanke and M.Ndolo, Oxford University Press, February, 2017. An early version was appeared as UNU/WIDER working paper, 2015 
This is the accepted version of an article that has been published by Elsevier in Structural Change and Economic Dynamics on 18 Aug 2018. Published version available from:

https://doi.org/10.1016/i.strueco.2018.07.005

Accepted version made available under CC-BY-NC-ND 4.0 International License from SOAS Research Online: http://eprints.soas.ac.uk/26304/

Nissanke, M(2017b), 'Introduction: Tracing Dynamics in Sub-Saharan Africa: Recent Progress and Future Challenges', Chapter 1 in Poverty Reduction in the Course of African Development, ed. by M.Nissanke and M.Ndolo, Oxford University Press, February, 2017

Nissanke, M. and E. Aryeetey (1998), Financial Integration and Development in Sub-Saharan Africa, Routledge, London and New York

Nissanke M. and E. Aryeetey (2006), 'Institutional Analysis of Financial Market Fragmentation in Sub-Saharan Africa: A Risk-Cost Configuration Approach’ WIDER Research Paper, 2006-87 (also Chapter 6 in Domestic Resource Mobilization and Financial Development, ed. by G. Mavrotas, Palgrave/Macmilan,

Nissanke, M and A. Kuleshov (2013), “An Agenda for International Action on Commodities and Development :Issues for EU Agenda Beyond the MDGs,", A Background Paper to the European Report on Development 2013, https:/ec.europa.eu/europeaid/sites/devco/files/erd-researchnissankeandkuleshovfinal-20130101_en.pdf

Nissanke, M. and Y. Shimomura (2013), "Institutional Evolution through Development Cooperation: an Overview", Chapter 1 in M.Nissanke and Y.Shimomura (eds), Aid as Handmaiden for Institution Development: A New Comparative Perspective, Palgrave/Macmillan

Nissanke, M. and E. Thorbecke (2008). Globalization and the Poor in Asia: Can Shared Growth Be Sustained? Basingstoke: Palgrave Macmillan for UNU-WIDER.

Nissanke, M. and E. Thorbecke (2010). The Poor under Globalization in Asia, Africa and Latin America, Oxford University Press

Obstfeld, M. (2015). Trilemma \& Trade-Offs: Living with Financial Globalization. BIS Working Paper, No. 480.

Ocampo, J.A. and R.Vos (2006), 'Policy space and the changing paradigm in conducting macroeconomic policies in developing countries’ BIS Papers No.36

Ostry, J. D., Ghosh, A. R., Habermeier, K., Laeven, L., Chamon, M., Qureshi, M. S. and Kokenyne, A. (2011) "Managing Capital Inflows: What Tools to Use?" International Monetary Fund (IMF) Staff Discussion Note SDN/11/06

Rey H. (2013), "Dilemma not Trilemma: The Global Financial Cycle and Monetary Policy Independence", Presented at the Jackson Hall Conference, August 2013

Robinson, J.A. and Q. N. Persons (2006), "State Formation and Governance in Botsuwana", Journal of African Economies 15, AERC Supplement (2006): 100-140

Rodrik, D (2011), "The Future of Economic Convergence", paper presented at the 2011 Jackson Hole Symposium of the Federal Reserve Bank of Kansas City, August 25-27, 2011

Saxegaard, M. (2006), 'Excess reserves and Effectiveness of Monetary Policy: Evidence from SubSaharan Africa', International Monetary Fund (IMF) Working Paper No. 06/115.

Stiglitz, J.E (2014), 'Reconstructing Macroeconomic Theory to Manage Economic Policy' NBER Working Paper 20517, September 2014

Stiglitz, J.E. and B.C. Greenwald (2014) Creating a Learning Society, Columbia University Press 
This is the accepted version of an article that has been published by Elsevier in Structural Change and Economic Dynamics on 18 Aug 2018. Published version available from:

https://doi.org/10.1016/i.strueco.2018.07.005

Accepted version made available under CC-BY-NC-ND 4.0 International License from SOAS Research Online: http://eprints.soas.ac.uk/26304/

Taylor, J. B. (2001): The Role of the Exchange Rates in Monetary-Policy Rules", AEA Papers and Proceedings, American Economic Review, May 2001 Vol.91. No.2, 263-267

Teranishi, J. (2000), “The Main Bank System”, in T. Okazaki and M. Okuno-Fujiwara (eds), The Japanese Economic System and its Historical Origins, Oxford University Press

Vines, D and S. Wills (2018), 'The rebuilding macroeconomic theory project: an analytical assessment', Oxford Review of Economic Policy (34 (1-2), 10-42

World Bank (2014), "Migration and Development Brief 22”, The World bank Group, Washington, April 11, 2014

Wren-Lewis (2018), 'Ending the microfoundations hegemony', Oxford Review of Economic Policy 34 (1-2), 55-69 
This is the accepted version of an article that has been published by Elsevier in Structural Change and Economic Dynamics on 18 Aug 2018 . Published version available from: https://doi.org/10.1016/i.strueco.2018.07.005

Accepted version made available under CC-BY-NC-ND 4.0 International License from SOAS Research Online: http://eprints.soas.ac.uk/26304/ 


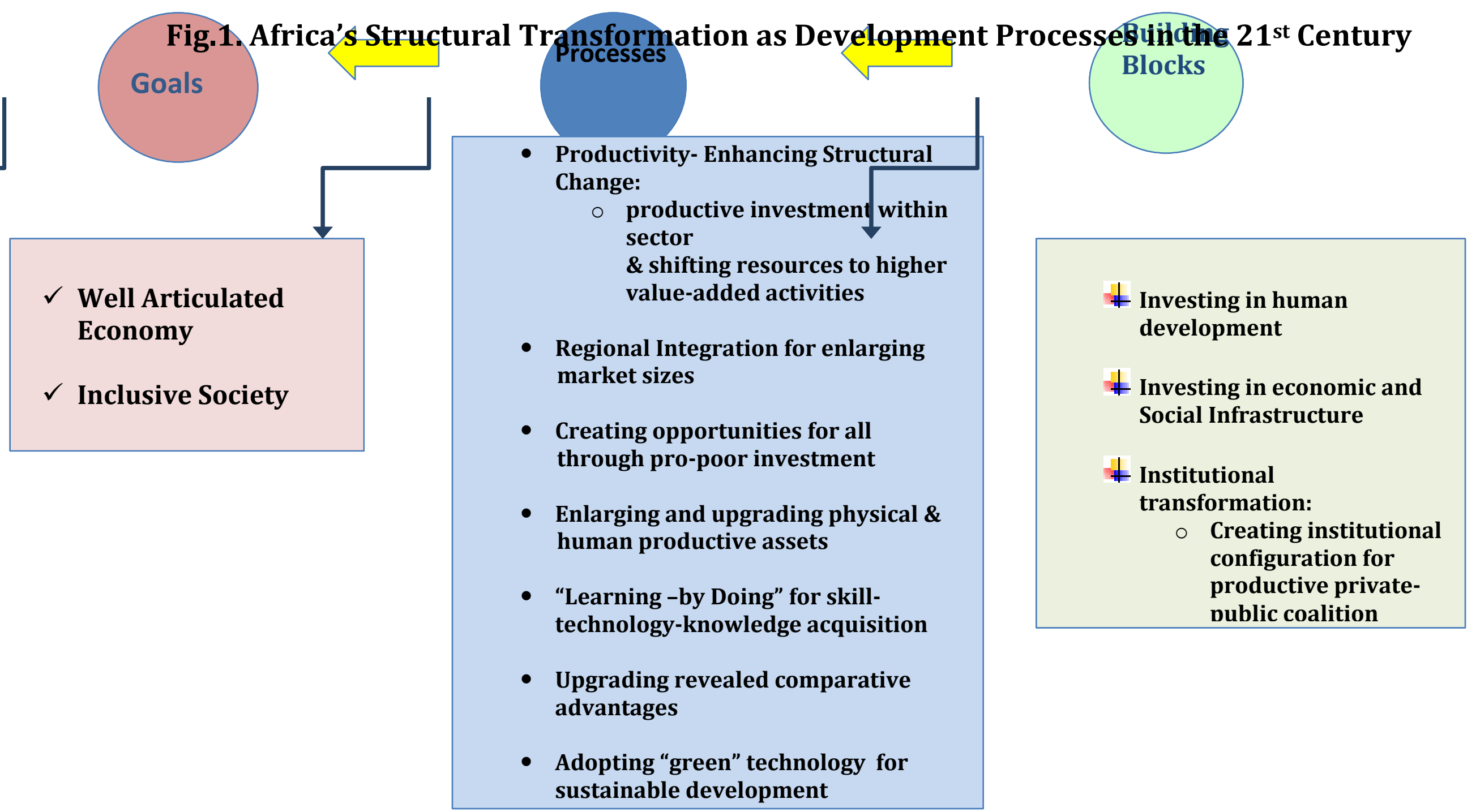


This is the accepted version of an article that has been published by Elsevier in Structural Change and Economic Dynamics on 18 Aug 2018. Published version available from:

https://doi.org/10.1016/i.strueco.2018.07.005

Accepted version made available under CC-BY-NC-ND 4.0 International License from SOAS Research Online: http://eprints.soas.ac.uk/26304/

Fig. 2 Macroeconomic Policies embedded in Development Strategic Planning for Structural Transformation

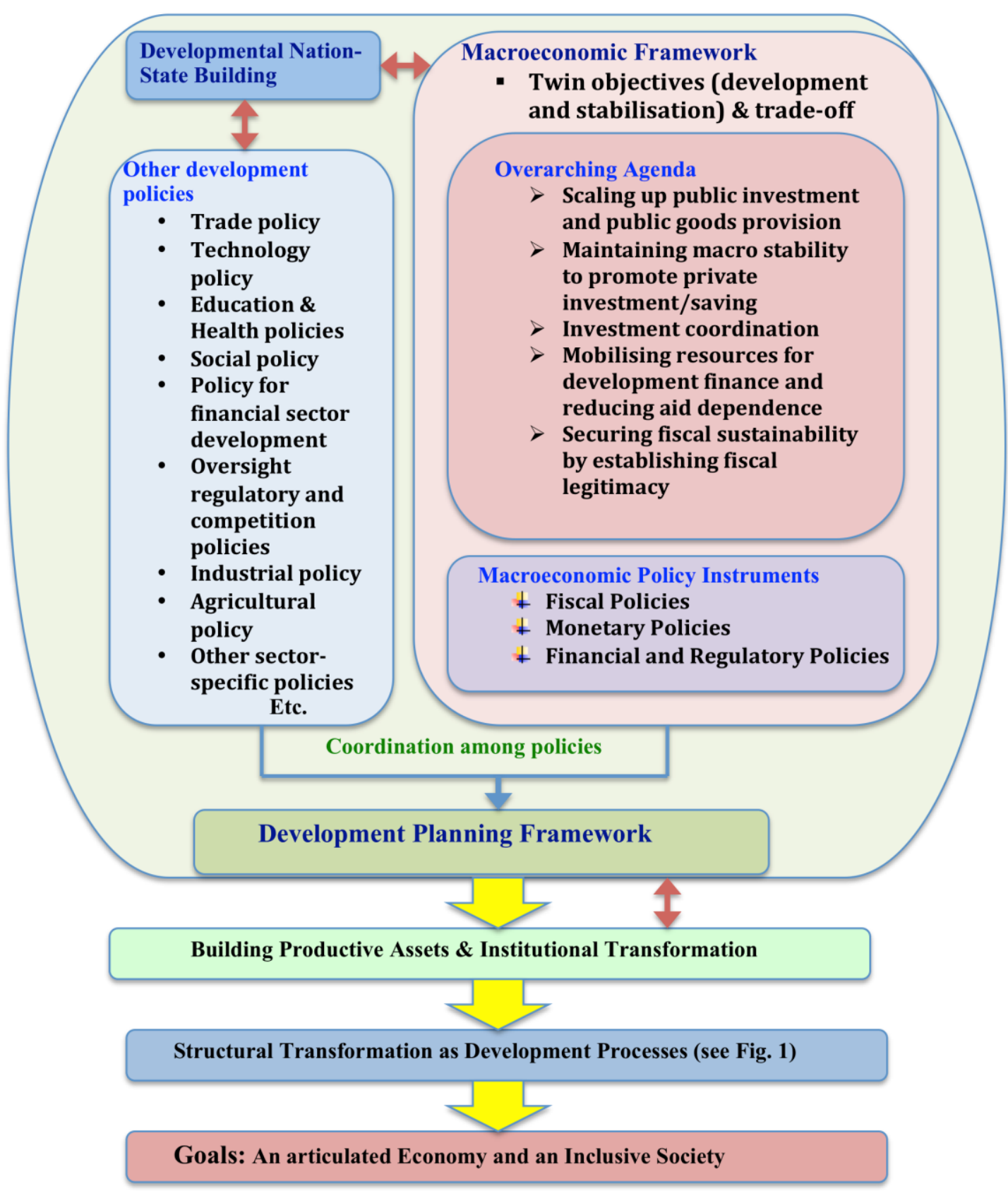


This is the accepted version of an article that has been published by Elsevier in Structural Change and Economic Dynamics on 18 Aug 2018. Published version available from:

https://doi.org/10.1016/i.strueco.2018.07.005

Accepted version made available under CC-BY-NC-ND 4.0 International License from SOAS Research Online: http://eprints.soas.ac.uk/26304/

\section{Fig. 3 Positioning in Macroeconomic Trilemma}

- the Impossible Trinity Thesis (Macroeconomic Trilemma)

Of exchange rate stability, financial openness and monetary independence, a country can choose to have any two attributes, but it can not choose all three

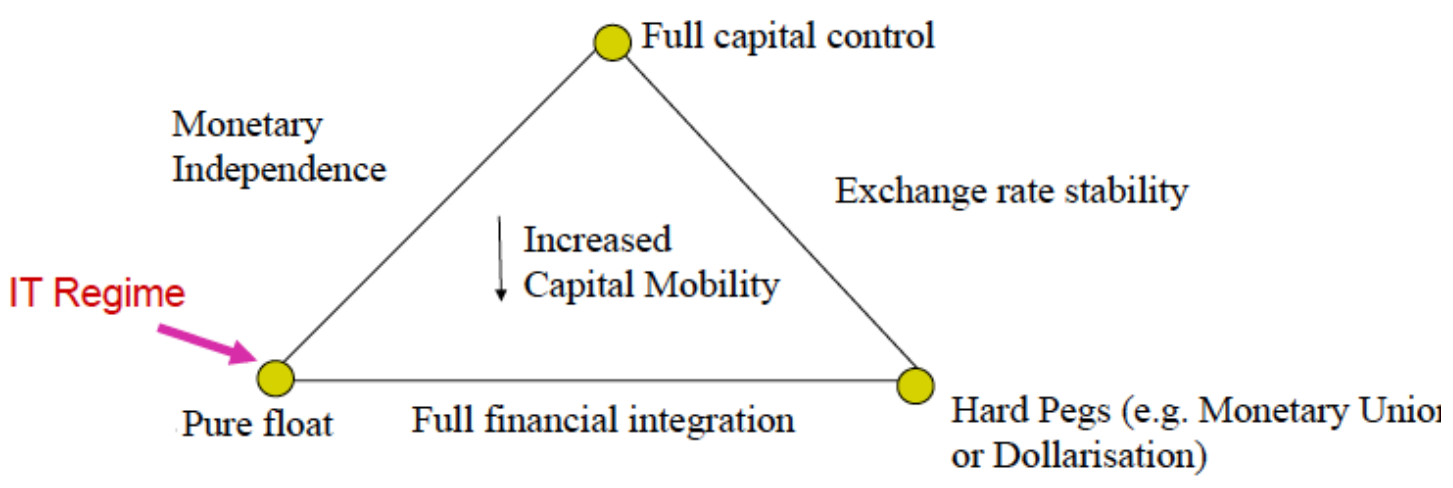

